\title{
WHY BROWNTOP IS BENT ON CREEPING
}

\author{
W. HARRIS \\ Grasslands Division, DSIR, Palmerston North
}

\section{Abstract}

Browntop invasion into hill country sown to ryegrass-white clover showed rapid vegetative spread over 2 years followed by dense tiller development. Initially a distribution mosaic formed, ryegrass and clover being positively associated with each other, but negatively associated with browntop. Subsequently, browntop spread into the ryegrass-clover microsites. Browntop ingressed under close, continuous grazing but not under lax, rotational grazing. Competitive interactions of clover and 'Grasslands Ruanui' and 'Grasslands Manawa' ryegrasses involved were partitioned. Browntop was markedly suppressed by interspecific shading under infrequent cutting, but survived to spread into spaces provided by nonpersistent ryegrass. Management to modify competition for light to control browntop is considered.

\section{VARIABILITY, TAXONOMY AND ECOLOGY}

Agrostis tenuis Sibth is a complex species aggregate which overlaps in morphological variation, and is interfertile with other recognized species of Agrostis (Jones, 1956a, b) . Consequently the taxonomic situation is confused, and for this reason the group of species A. gigantea, A tenuis, and A. stolonifera is considered as one entity in this paper. This grouping encompasses a range of habits from erect, rhizomatous types characteristic of A. gigantea, through rhizomatous-stoloniferous forms found in $A$. tenuis, to prostrate stoloniferous $A$. stolonifera. The group is also very phenotypically plastic, environmentally induced variation of individuals being considerable (Bradshaw, 1958a). Braidshaw $(1958 \mathrm{~b})$ also observed that hybrids between morphologically distinct forms of Agrostis were more vigorous than the respective parents and he has recorded distinct population differentiation within $A$. tenuis - e.g., lead-tolerant ecotypes (Bradshaw, 1960) .

Application of common names to the Agrostis species is also confused. However, examination of these names provides a description of some ecological characteristics of the group. The ability to creep vegetatively by stolons or rhizomes is expressed in the name creeping bent, usually applied to $A$. stolonifera. 
Given space, internodes of rhizomes or stolons elongate to provide rapid lateral spread, and from nodes new tillers emerge and secondary points of colonization are established (Kershaw, 1958) . If this spread continues without inter-specific shading, as in closely continuously grazed swards or lawns, a dense turf of tillers arising from stems with very short internodes is formed. With time, under poor nutritional conditions, a dense mat of tillers, stolon, rhizome and root tissue, both living and dead, is formed, and this sod-bound state physically impedes the ingress and growth of other species. Common bent is the name most often given to A. tenuis in the United Kingdom (Clapham et al., 1962). By definition, a common is an area of unenclosed waste land, community owned, with shared rights of pasturage and recreational use, and bents are stiff-stemmed grasses, particularly those which are characteristic of heath or unenclosed pasture. In this definition there is a part description of the typically occupied habitat of A. tenuis in New Zealand, namely poorer class pastoral land on which careful control of grazing is not practised. For A. tenuis, Levy (1924) gave the (alternative common names of colonial bent and browntop; the latter, referring to the colour of the seedhead, having become the most frequently used in New Zealand colloquialism. However, use of the name browntop also relates to the dried-out brown herbage of the grass during summer, Levy (1928) observed that the distribution of browntop in New Zealand showed a preference for wetter sites, but it is important to note that browntop is better adapted to survive drought and associated overgrazing by means of rhizome-borne apices below the soil surface, than are ryegrasses in general.

Levy ( 1924, 1928) saw browntop as an occupier of soils of intermediate fertility between the high fertility situation favourable to the growth of ryegrass, cocksfoot, crested dogstail, Poa pratensis and white clover, and the low fertility situation characterized by Danthonia pilosa and suckling clover. His opinion of browntop is made clear in the following statement: "The manuring-out of browntop and the manuring in of ryegrass, cocksfoot, crested dogstail, and white clover should be regarded as a grasslands maxim" (Levy, 1928) . J ackman and Mouat (1974) more specifically consider mineral nutritional responses of browntop at this conference. In relation to this, the main concept intended to be developed in this paper is that the "manuring out" of browntop will be more readily achieved rhrough manipulating effects of competition for light, by recognizing the 
susceptibility of ryegrasses to close, continuous grazing, especially in summer drought conditions, and that these effects can be controlled by grazing management.

\section{INGRESS OF BROWNTOP INTO HILL COUNTRY}

Successional study of hill country pasture sown on a prepared seedbed in March 1966 with a 50:50 mixture of Lolium perenne L. 'Grasslands Ruanui' perennial ryegrass and Lolium (multiflorum x perenne) 'Grasslands Manawa' short-rotation ryegrass at $40 \mathrm{~kg} / \mathrm{ha}$ together with $3 \mathrm{~kg} / \mathrm{ha}$ Trifolium repens L. 'Grasslands Huia' white clover has prwided the frequency occurrence, tiller densities, and association data presented in Fig. 1 and Table 1. The site (Raumai hill soil") was topdressed with

$\%$ occurRENCE

TILLERS /PLUG

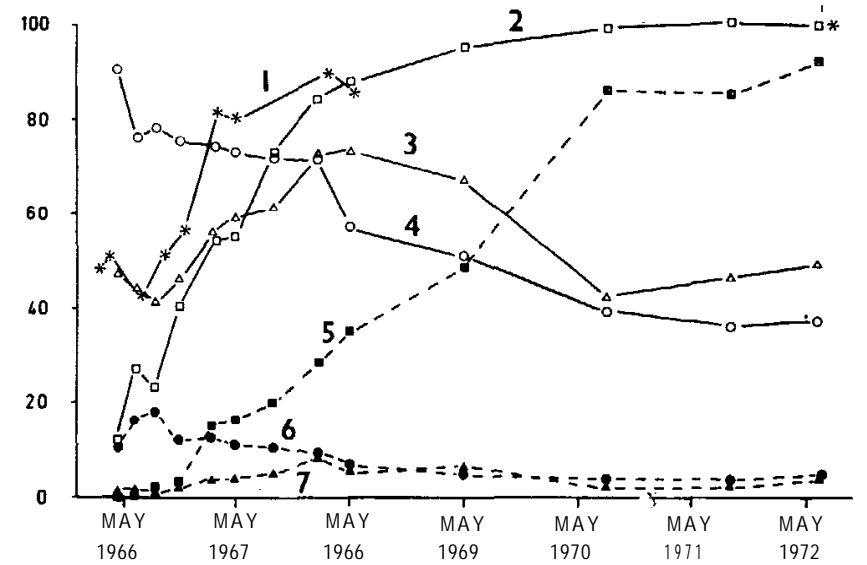

FIG. 1: Successional changes in species presence and densities in a hill country pasture.

1. \% proportion of Ruanui in ryegrass population originating from a Manawa-Ruanui mixture.

2. $\%$ presence browntop.

3. \% presence white clover.

4. $\%$ presence ryegrass.

5. tiller density browntop

6. tiller density ryegrass
7. shoot density white clover]

*Full details of soil types are given in Cowie (1972) and Cowie et al. (1972). 
$336 \mathrm{~kg} / \mathrm{ha}$ potassic superphosphate and $224 \mathrm{~kg} / \mathrm{ha}$ molybdic superphosphate in the first year. Subsequently there was an annual application of $224 \mathrm{~kg} / \mathrm{ha}$ superphosphate, molybdic super-

TABLE 1: ASSOCIATION BETWEEN SPECIES IN A HILL COUNTRY PASTURE FOR 7 YEARS.

Data obtained using plug (diameter $5.1 / \mathrm{cm}$ ) sampling technique of Mitchell and Glenday (1958). Tests of association as detailed by Greig Smith (1957).

\begin{tabular}{|c|c|c|c|c|c|c|}
\hline \multicolumn{7}{|c|}{ Occurrence of Species in Association \% } \\
\hline \multirow{2}{*}{$\begin{array}{c}\text { Sample } 1 \\
\text { Date }\end{array}$} & \multirow{2}{*}{$\begin{array}{l}\text { No. of } \\
\text { Plugs }\end{array}$} & \multirow{2}{*}{ Neither } & \multirow{2}{*}{ Ryegrass } & \multirow{2}{*}{ Browntop } & \multirow{2}{*}{$\begin{array}{c}\text { Ryegrass } \\
+ \\
\text { Browntop }\end{array}$} & \multirow{2}{*}{$\begin{array}{r}\text { Direction of } \\
\text { Association, } \\
\chi^{2} \text { and signif. }\end{array}$} \\
\hline & & & & & & \\
\hline Мау 1966 & 100 & 6.0 & 82.0 & 4.0 & 8.0 & $-3.5\left(^{*}\right)$ \\
\hline Maу 1967 & 503 & 5.6 & 27.4 & 23.7 & 43.3 & $-17.4^{* * *}$ \\
\hline May 1968 & 500 & 2.4 & 10.6 & 40.8 & 46.2 & $-17.5^{* * *}$ \\
\hline May 1969 & 494 & 1.6 & 2.4 & 46.8 & 49.2 & $\mathrm{~ns}$ \\
\hline Aug. 1970 & 495 & 0.6 & 0.4 & 61.0 & 38.0 & $\mathrm{~ns}$ \\
\hline Sep. 1971 & 499 & 0.0 & 0.4 & 63.9 & 35.7 & $\mathrm{~ns}$ \\
\hline \multirow[t]{2}{*}{ Jun. 1972} & 500 & 0.2 & 0.4 & 63.0 & 36.4 & $\mathrm{~ns}$ \\
\hline & & Neither & $\begin{array}{l}\text { White } \\
\text { Clover }\end{array}$ & Browntop & $\begin{array}{c}\text { Clover }+ \\
\text { Browntop }\end{array}$ & \\
\hline Мay 1966 & 100 & 47.0 & 41.0 & 5.0 & 7.0 & ns \\
\hline M a y 1967 & 503 & 11.7 & 21.4 & 30.4 & 36.5 & $-4.3 *$ \\
\hline May 1968 & 500 & 2.8 & 10.2 & 24.4 & 62.6 & $\mathrm{~ns}$ \\
\hline May 1969 & 494 & 1.8 & 2.8 & 31.0 & 64.4 & $\mathrm{~ns}$ \\
\hline Aug. 1970 & 495 & 0.4 & 0.6 & 57.2 & 41.8 & $\mathrm{~ns}$ \\
\hline Sep. 1971 & 499 & 0.2 & 0.2 & 53.9 & 45.7 & $\mathrm{~ns}$ \\
\hline \multirow[t]{2}{*}{ Jun. 1972} & 500 & 0.2 & 0.4 & 50.7 & 48.7 & $\mathrm{~ns}$ \\
\hline & & Neither & Ryegrass & $\begin{array}{c}\text { White } \\
\text { Clover }\end{array}$ & $\begin{array}{c}\text { Clover }+ \\
\text { Ryegrass }\end{array}$ & \\
\hline May 1966 & 100 & 5.0 & 48.0 & 5.0 & 42.0 & $\overline{\mathrm{ns}}$ \\
\hline Mayf967. & 503 & 18.1 & 24.0 & 11.1 & 46.8 & $+32.5 * * *$ \\
\hline May 1968 & 500 & 14.4 & 12.4 & 28.8 & 44.4 & $+8.6^{* *}$ \\
\hline May 1969 & 494 & 17.8 & 15.2 & 30.8 & 36.2 & ns \\
\hline Aug. 1970 & 495 & 37.4 & 20.2 & 24.0 & 18.4 & $+3.1\left(^{*}\right)$ \\
\hline Sep. 1971 & 499 & 39.1 & 15.2 & 24.9 & 20.8 & $+16.3^{* * *}$ \\
\hline Jun. $1972 \dagger$ & 500 & 32.7 & 18.2 & 30.7 & 18.4 & $\mathrm{~ns}$ \\
\hline \multicolumn{7}{|c|}{$\begin{array}{l}\text { Terrace site† } \\
\text { on Tokomaru }\end{array}$} \\
\hline silt loam & 498 & 0.4 & 24.7 & 1.6 & 73.3 & $\mathrm{~ns}$ \\
\hline
\end{tabular}


phosphate being used each third year. The pasture was continuously set-stocked with 10 to 15 sheep/ha.

There was a rapid reversion to a browntop-dominant pasture, even though seedbed preparation for the class of country was good and destroyed most of the pre-existing browntop. However, regeneration from undestroyed pieces oh turf and the considerable buried seed population of browntop provided an adequate base for rapid re-invasion. This had two phases, first a rapid spread to a frequency occurrence of $88 \%$ two years after sowing, thence a consolidation of turf within the occupied 'areas by an increase of tiller numbers (Fig. 1). White clover also showed a phase of vegetative spread from established plants, but the second phase of browntop invasion 'appeared to squeeze out both white clover and ryegrass.

The greatest loss of ryegrass plants was from the Manawa fraction of the population; consequently 1 year after sowing Ruanui formed $80 \%$ of the ryegrass population, and after 6 years $99.5 \%$. The very early $14 \%$ reduction in the occurrence of ryegrass (Fig. 1) contributed to the formation of significant associations, ryegrass and white clover occurring more frequently together but were both negatively associated with browntop (Table 1). Observations suggested that this related to a soil fertility mosaic, developed from the effects of topography, the pattern of return of dung and urine, and the removal of topsoil in patches during seedbed preparation, the growth and association of ryegrass and white clover being fostered on higher fertility sites. Progressively, Qrowntop displaced or replaced ryegrass and clover in these micro-sites, breaking down their association. This dissociation may well have disrupted pathways of nitrogen transfer between white clover and ryegrass which do not involve cycling through grazing animals. For comparison, a parallel study on higher fertility, sheep-grazed terrace country (Table 1) showed the much greater content and the more frequent joint occurrence of ryegrass and white clover in the pasture after 6 years.

\section{EFFECTS OF FREQUENCY AND INTENSITY OF GRAZING}

On a fertile soil (Karapoti brown sandy loam) marked ingress of browntop occurred where there was close and continuous grazing by sheep, but with lax-rotational grazing browntop was absent (Table 2, Harris and Brougham, 1968). Although the ingress of browntop into the close and continuously g-razed pasture involved development af a fertility mosaic through nutrient transfer, and the non-persistence of Manawa ryegrass, 
the important factor excluding browntop from the lax-rotationally grazed swards was interspecific shading, browntop being suppressed by this because fuller expression of height differences allowed ryegrass and white clover to overtop the more prostrate browntop. This may appear contradictory to the observation that browntop is more shade-tolerant than either L. perenne (Myhr and Saebo, 1969) or white clover, but the intense shade developed under a fully förmed canopy of ryegrass-white clover far exceeds the shade tolerance of browntop.

TABLE 2: PERCENTAGE PRESENCE AND TILLER AND NODE DENSITIES OF RYEGRASS, WHITE CLOVER AND BROWNTOP IN TWO GRAZING SYSTEMS.

Data obtained using plug sampling technique of Mitchell and Glenday (1958)

\begin{tabular}{|c|c|c|c|c|c|}
\hline \multirow{2}{*}{ Grazing System } & & & \multicolumn{3}{|c|}{ Species } \\
\hline & & & Ryegrass & White Clover & Browntop \\
\hline \multicolumn{6}{|l|}{ Close-continuous: } \\
\hline Presence $(\%)$ & & & 94.7 & 69.3 & 35.0 \\
\hline Tiller or node & no./plug ,... & " & 30.1 & 8.9 & 13.4 \\
\hline \multicolumn{6}{|l|}{ Lax-rotational: } \\
\hline Presence (\%) & & . & 67.3 & 86.0 & - \\
\hline Tiller or node & no./plug .... & $\ldots$ & 6.3 & 4.6 & - \\
\hline
\end{tabular}

\section{DEFOLIATION AND INTERSPECIFIC COMPETITION}

Competition studies have shown differences in the abilities of ryegrass cultivars and white clover to suppress browntop by interspecific shading (Fig. 2). When grown in 50: 50 mixtures, both Manawa and Ruanui suppressed browntop in the establishment year, more so with infrequent than with frequent cutting. Slower establishment of white clover allowed browntop to compete successfully in the first year, browntop providing the greater part of the yield of this mixture, especially where cutting was frequent. The cutting frequency treatment was discontinued in early spring of the second year, when all plots were cut at monthly intervals. Under this system browntop was held at very low levels in those plots infrequently cut in the first year, but continued to produce a large part of the yield of plots which had been cut frequently. This marked suppression of browntop occurred in summer-autumn 04 the first year when temperature and moisture conditions gave white clover a growth advantage, and a long interval between defoliations allowed petiole extension 
WHY BROWNTOP CREEPS
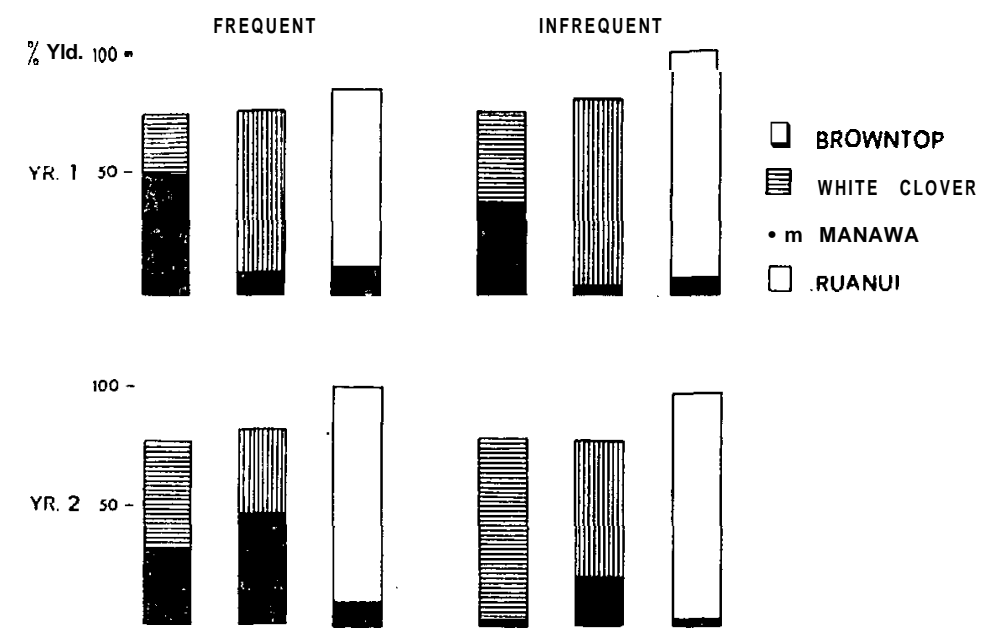

FIG. 2: Content of browntop in mixtures with Ruanui ryegrass, Manawa ryegrass and white clover under two cutting frequencies in two years. Contents nre shown as percentages relative to the yield of the highest yielding mixture in each year.

of white clover leaves to provide a canopy which markedly shaded the browntop turf.

Although Manawa most strongly suppressed browntop in the early stages of sward establishment, this cultivar's lack of persistence, related to susceptibility to drought and fre-quent-close defoliation, opened up the sward to provide gaps into which browntop spread vegetatively.

\section{PRACTICAL IMPLICATIONS}

The description of rapid ingress of browntop into a wellfertilized pasture sown with ryegrass-white clover is a common situation on wetter hill country where set-stocking aimed at full utilization is practised. The question posed is whether application of rotational grazing and spelling of pastures at certain times of the year will increase white clover and ryegrass content, and whether such practice would be in the best interest of the stock and other aspects of hill country management. It is important to state several prerequisites for applying grazing management designed to bring about a shift from browntop to ryegrass-white clover dominance. These are, adequate subdivision for stock control, to be out of the. development phase involving 
control of secondary regrowth, a good base of white clover and to some extent ryegrass in the sward, and soil fertility not seriously limiting the growth of white clover. Relevant observations are that the greatest relative growth advantages of ryegrass and white clover over browntop are in winter-early spring and in late summer-autumn, respectively, and that in spring-early summer dry matter production from browntop and perennial ryegrass are similar (Harris and Thomas, 1972). Consequently, to maintain maximum suppression of browntop by shading, spelling during late summer-early autumn will provide fullest development of a white clover canopy, and rotational grazing continued into the winter should provide further suppression of browntop if sufficient ryegrass is present. This ties in well with the practice of autumn-saved pasture. The objective in spring and early summer should be to aim at full utilization by maximum stocking to prevent development of rank, unpalatable browntop which will inhibit summer growth of white clover. This could fit in with a system of set-stocking during lambing, and the removal of surplus herbage where possible for conservation.

Where a dense browntop turf is formed, its improvement back to ryegrass-white clover requires the breaking down of this turf by cultivation, chemical renovation, or very heavy mob-stocking. This latter practice could well work in with a system where pastures with high clover and ryegrass coatent could be spelled in late summer and autumn, and browntop-dominant pastures mob-stocked, fertilized, and oversown with persistent varieties of ryegrass and white clover.

As clearly stated by Levy (1970), the value of browntop as a successional grass on low to medium fertility hill country should not be overlooked as in these situations it is an efficient dry matter producer, 'a useful soil binder, and an inhibitor of secondary regrowth. For these reasons browntop will remain a useful addition to seeds mixtures sown for pasture development out of forest and scrub. For the next step forward, from browntopdominant to ryegrass-dominant pasture, the buried seed population of browntop and vegetative regeneration will provide a buffer grass should ryegrass fail to persist.

\section{ACKNOWLEDGEMENTS}

Dr R. W. Brougham has collaborated in the conduct of experiments cited and in the development of concepts put for- 
ward. The staff of the Herbage Dissection Laboratory, Grasslands Division, contributed substantially to the collection of the data presented.

\section{REFERENCES}

Bradshaw, A. D., 1958a: Heredity, 12: 143. 1958b: New Phytol., 57: 66-84.

1960: Ibid., 59: 92-103.

Clapham, A. R.; Tutin, T. G.; Warburg, E. F., 1962: Flora of the British Isles, 2nd ed. University Press, Cambridge. 553 pp.

Cowie, J. D., 1972: N.Z. Soil Bureau Pub. 538.

Cowie, J. D.; Kear, B. S.; Orbell, G. E., 1972: N.Z. Soil Bureau Map 102 .

Greig-Smith, P., 1957: Quantitative Plant Ecology. Butterworths, London, pp. 85-98.

Harris, W.; Brougham, R. W., 1968: N.Z. /l agric. Res., 11: 15-38.

Harris, W.; Thomas, V. J., 1972: Ibid., 15: 19-32.

Jackman, R. H.; Mouat, M. C. H., 1974: Proc. N.Z. Grassld Ass., 35: 95-100.

Jones, K., 1956a: I. Genet., 54: 377-93.

- 1956b: Ibid., 54: 394-Q

Kershaw, K. A., 1958: J. Ecol., 46: 571-92.

Levy, E. B., 1924: N.z. Il Agric., 28: 73-91.

1928: Ibid., 36: 1-18.

1970: Grasslands of New Zealand. Government Printer. Wellington. $374 \mathrm{pp}$

Mitchell, K. Glenday, A. C., 1958: N.Z. agdic. Res., 1: 305.

Myhr, K.; Saebo, S., 1969: Forsk. Fors. Landbr., 20: 297-315. 